\title{
FEATURED PHOTO
}

\section{EVIDENCE FOR SUSPENSION OF PREBASIC MOLT IN A WHITE-EYED VIREO}

\author{
BLAINE H. CARNES, 917 Tupelo Dr., Coppell, Texas 75019; \\ blainehcarnes@gmail.com
}

ABIDAS ASH, University of Belize Environmental Research Institute, P.O. Box 340, Belmopan, Belize, Central America; aash@ub.edu.bz

In most migratory North American passerines the preformative and prebasic molts occur largely on the breeding grounds in late summer following nesting (Pyle 1997), but there are some exceptions to this pattern. Some species initiate molt on the breeding grounds, then suspend it over migration, before resuming and completing molt in the nonbreeding range (Howell 2010). Within a species, populations may differ by latitude in the timing and location of molt, with southern populations breeding and molting earlier than northern ones (Pyle et al. 2018).

At the levels of both the species (Pyle et al. 2009) and the individual (Gow and Stutchbury 2013), numerous species move long distances from the breeding grounds to molt at a site short of the winter range, a pattern known as "molt migration." Among species that generally molt on their breeding grounds, second-year individuals, failed breeders, or birds with lower-quality territories may migrate or disperse elsewhere to molt (Pyle et al. 2018). In some cases, the dense cover and nutrition necessary for feather growth may not be available in their breeding territories (Gow and Stutchbury 2013).

The White-eyed Vireo (Vireo griseus) is typical of the Vireonidae in having a partial to incomplete (usually eccentric) preformative molt and complete prebasic molt (Pyle 1997). In their broad-scale assessment of migration or dispersal from breeding territories to areas of molt in North American landbirds, Pyle et al. (2018) concluded that White-eyed Vireos have a high probability of molting on their breeding territories rather than dispersing to molt elsewhere. Here we present the first evidence of a White-eyed Vireo suspending prebasic molt during migration and resuming molt in its winter range.

On 20 and 22 February 2018, we captured a single molting White-eyed Vireo while banding under the protocol "Monitoreo de Sobrevivencia Invernal" (DeSante et al. 2005) at Freshwater Creek Forest Reserve, Orange Walk district, Belize. We aged it as older than its second calendar year on the basis of the primary coverts being broad and dusky with distinct greenish edging and not contrasting with the secondary coverts in color or quality (Pyle 1997). As seen in the photo on this issue's back cover, the bird was symmetrically molting secondaries $2-7$, and secondary 9 was contrastingly fresher than secondary 8.

This molt could be interpreted as an extensive and eccentric prealternate molt, as seen in a few other North American passerines of exposed habitats such as the Yellow Warbler (Setophaga petechia), Nelson's Sparrow (Ammodramus nelsoni), Indigo Bunting (Passerina cyanea), and Lesser Goldfinch (Spinus psaltria) (Pyle 1997, Pyle and Kayhart 2010, Wolfe and Pyle 2011). But we do not believe this White-eyed Vireo represented such molt because prealternate molt is unknown in this species, and most passerines that replace primaries or secondaries in the prealternate molt also replace a few secondary coverts (Pyle 1997, Wolfe and Pyle 2011). The secondary coverts in this White-eyed Vireo lack contrast, indicating that they are all from the bird's definitive prebasic molt.

Passerines generally initiate flight-feather molt at two or three nodes, with the primaries being replaced distally from the innermost primary. Once approximately 


\section{FEATURED PHOTO}

half the primaries have been replaced, replacement of the secondaries begins at the outermost and proceeds proximally (Johnson and Wolfe 2018). Molt of the tertials often begins partway through replacement of the primaries and typically proceeds in the order s8, s9, and s7 (Johnson and Wolfe 2018).

In this White-eyed Vireo, the greater wear of the primaries, secondary 1, and secondary 8 in comparison to the relatively fresh secondary 9 and the molting secondaries 2-7 indicates that these feathers had all been replaced several weeks to several months earlier, suggesting a suspension of molt as in other passerines in which molt of the remiges is typically interrupted, such as the Lesser Goldfinch and adults of the Red-eyed Vireo (Vireo olivaceus) (Howell 2010).

White-eyed Vireos with territories in relatively poor habitat molt later than do those in good habitat (Butler et al. 2008), likely because of renesting after nest failure (Hopp et al. 1995). The timing of their molt also varies in correlation with the El Niño-Southern Oscillation, because in wet years they nest at least twice and initiate molt later (Butler et al. 2008). However, winter survival and subsequent reproductive success of individuals breeding and molting late may be reduced, in part because their feather quality and body condition may be reduced (Nilsson and Svensson 1996). Butler et al. (2008) suggested that late-molting adult White-eyed Vireos facing an oncoming migration compensate by retaining high-quality feathers. One such form of compensation may be to suspend molt, then resume it in the winter range.

It is possible that suspension of molt over migration is a semiregular response of passerines for late-breeding individuals from marginal habitats or northern populations dealing with the physiological and temporal demands of molt. We recommend that ornithologists and banders be aware of and investigate the possibility of suspended prebasic molt in other species not known to undergo molt migration.

Our research was made possible by a joint initiative of the University of Belize Environmental Research Institute, Corozal Sustainable Future Initiative, Black Rock Lodge, Belize Audubon Society, and the Institute for Bird Populations. Eduany Muñoz and Louis Peña Angel assisted in the field. Edits and suggestions by Dan Cooper, Jeremiah Kennedy, Eliseo Parra, and two anonymous reviewers greatly improved the manuscript.

\section{LITERATURE CITED}

Butler, L. K., Hayden, T. J., and Romero, L. M. 2008. Prebasic molt of Black-capped and White-eyed Vireos: Effects of breeding site and the El Niño-Southern Oscillation. Condor 110:428-440; doi 10.1525/cond.2008.8565.

DeSante, D. F., Sillett, T. S., Siegel, R. B., Saracco, J. F., Romo de Vivar Alvarez, C. A., Morales, S., Cerezo, A., Kaschube, D., and Milá, B. 2005. MoSI (Monitoreo de Sobrevivencia Invernal): Assessing habitat-specific overwintering survival of neotropical migratory landbirds, in Bird Conservation Implementation and Integration in the Americas (C. J. Ralph and T. D. Rich, eds.), pp. 926-936. Gen. Tech. Rep. PSW-GTR-191. U.S. Forest Service, Pac. Southwest Res. Sta., Arcata, CA

Gow, E. A., and Stutchbury, B. J. M. 2013. Within-season nesting dispersal and molt dispersal are linked to habitat shifts in a neotropical migratory songbird. Wilson J. Ornithol. 125:696-708; doi 10.1676/13-015.1.

Hopp, S. L., Kirby, A., and Boone, C. A. 1995. White-eyed Vireo (Vireo griseus), in the Birds of North America (A. F. Poole and F. B. Gill, eds.), no. 168. Acad. Nat. Sci., Philadelphia; doi 10.2173/bna.168.

Howell, S. N. G. 2010. Molt in North American Birds. Houghton Mifflin Harcourt, New York.

Johnson, E. I., and Wolfe, J. D. 2018. Molt in Neotropical Birds: Life History and Aging Criteria. CRC Press, New York. 


\section{FEATURED PHOTO}

Nilsson, J.-A., and Svensson, E. 1996. The cost of reproduction: A new link between current reproductive effort and future reproductive success. Proc. Royal Soc. London B 263:711-714; doi 10.1098/rspb.1996.0106.

Pyle, P. 1997. Identification Guide to North American Birds, part 1. Slate Creek Press, Bolinas, CA.

Pyle, P., and Kayhart, R. 2010. Replacement of primaries during the prealternate molt of a Yellow Warbler. N. Am. Bird Bander 35:178-181.

Pyle, P., Leitner, A., Lozano-Angulo, L., Avilez-Teran, F., Swanson, H., GómezLimón, E., and Chambers, M. K. 2009. Temporal, spatial, and annual variation in the occurrence of molt-migrant passerines in the Mexican monsoon region. Condor 111:583-590; doi 10.1525/cond.2009.090085.

Pyle, P., Saracco, J. F., and DeSante, D. F. 2018. Evidence of widespread movements from breeding to molting grounds by North American landbirds. Auk 135:506-520; doi 10.1642/AUK-17-201.1.

Wolfe, J. D., and P. Pyle. 2011. First evidence for eccentric prealternate molt in the Indigo Bunting (Passerina cyanea): Possible implications for adaptive molt strategies. W. Birds 42:257-262.

Accepted 28 November 2018 